PROCEEDINGS OF THE UNITED STATES NATIONAL MUSEUM

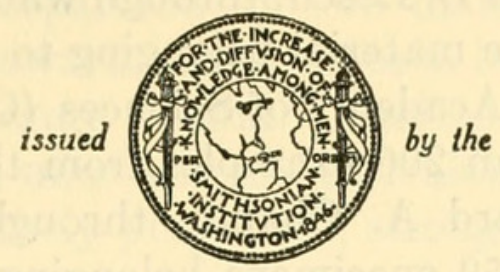

SMITHSONIAN INSTITUTION

U. S. NATIONAL MUSEUM

\title{
A REVISION OF THE NEARCTIC SPECIES OF THE BEETLE GENUS MELIGETHES (NITIDULIDAE)
}

\section{By Alan M. Easton}

The representation in North America of the genus Meligethes Stephens was first discovered by LeConte, who, in 1857, described three species-rufimanus, moerens, and seminulum. In 1859 he added to this list saevus and ruficornis. Gemminger and Harold in their catalog published in 1868 retained at five the total of Nearctic species, though the trivial name mutatus Harold was introduced in place of ruficornis LeConte by reason of the preoccupation of the latter (Heer, 1841). Horn, in 1879, when revising the Nitidulidae of the United States, added a further species, $M$. pinguis, but the recognition of the identity of rufimanus LeConte and moerens LeConte served to maintain the previous total, in which no further change was noted at the publication of the Leng catalog in 1920, or in 1943 when Parsons again revised the Nitidulidae of North America. A sixth species, M. simplipes Easton, was described in 1947.

The present paper introduces two further species, $M$. canadensis, new species, and $M$. atratus Olivier, already well known in the Old World. $M$. seminulum LeConte is shown to be identical with the Palaearctic $M$. nigrescens Stephens, while $M$. aeneus Fabricius is deleted from the list, it being asserted that its representatives in North America are conspecific with $M$. rufimanus LeConte and distinct from the Palaearctic species.

In compiling this revision I am fully conscious of the debt I owe to my many friends across the Atlantic without whose untiring help in sending material its inception would have been impossible. So many have rendered invaluable assistance in this and other ways 
that it becomes impracticable to list them. Outstanding among them, however, are Mr. Hugh B. Leech, through whose courtesy I have been enabled to study all the material belonging to this genus in the collections of the California Academy of Sciences (CAS); Mr. H. Dietrich, who kindly sent on loan 206 examples from the collection of Cornell University; Mr. Edward A. Chapin, through whose cooperation I received for revision 259 specimens belonging to the U. S. National Museum (USNM), Mr. E. A. Dickason of Oregon State College; Prof. R. E. Larson; Mr. L. R. Gillogly; and Mr. J. W. Green. To these gentlemen, as to the many others whose names are not here recorded, grateful acknowledgement is made of the important part which they have played in bringing about the completion of this paper.

\section{Meligethes canadensis, new species}

Figure $76, a-f$

MALE: Length, $2.2 \mathrm{~mm}$.; width, $1.3 \mathrm{~mm}$. Oval, somewhat elongate, moderately convex, shining black, with second segment of antennae and segments 1-4 of all tarsi brown; short fine inconspicuous pubescence.

Head strongly transverse, triangular, slightly convex. Clypeus with anterior margin straight. Punctures equal in size to the eye facets and separated by one-half to one diameter, the surface between finely microscopically reticulate. Antennae black, except the second segment pale brown, and the third brownish black, the club of medium size, about twice as long and $2 \frac{1}{4}$ times as wide as the first antennal segment.

Pronotum nearly twice as wide as long (1.1: $0.6 \mathrm{~mm}$.), with sides almost straight in the middle, strongly rounded inwards in front, less so towards the base. Front margin almost straight, except at its extremities where the front angles are slightly prominent, little more than half as long as the hind margin. Hind margin extremely feebly sinuate on each side of the scutellum, hind angles obtuse, bluntly pointed. Upper surface moderately strongly convex, feebly explanate towards the hind angles; sides narrowly bordered. Punctures slightly coarser than those of the head, and on the disc equally close, towards the base separated by 1 to $1 \frac{1}{2}$ diameters, surface between finely microscopically reticulate.

Elytra a little more than twice as long as the pronotum (1.4: 0.6 $\mathrm{mm}$.), scarcely longer than broad, at base as wide as base of pronotum, gently rounded at the sides and somewhat narrowed posteriorly, the apex of each being gradually rounded off, and having an extremely minute tooth at the sutural angle. Moderately strongly convex, 
sides very narrowly bordered. Punctures on disc as course as those of the pronotum but separated by two diameters, gradually much finer and more diffuse towards the apex, each bearing a fine recumbent hair reaching the puncture behind. Surface between with distinct, fine, chiefly transverse, microscopical reticulation.

Scutellum finely diffusely punctured, strongly reticulate.
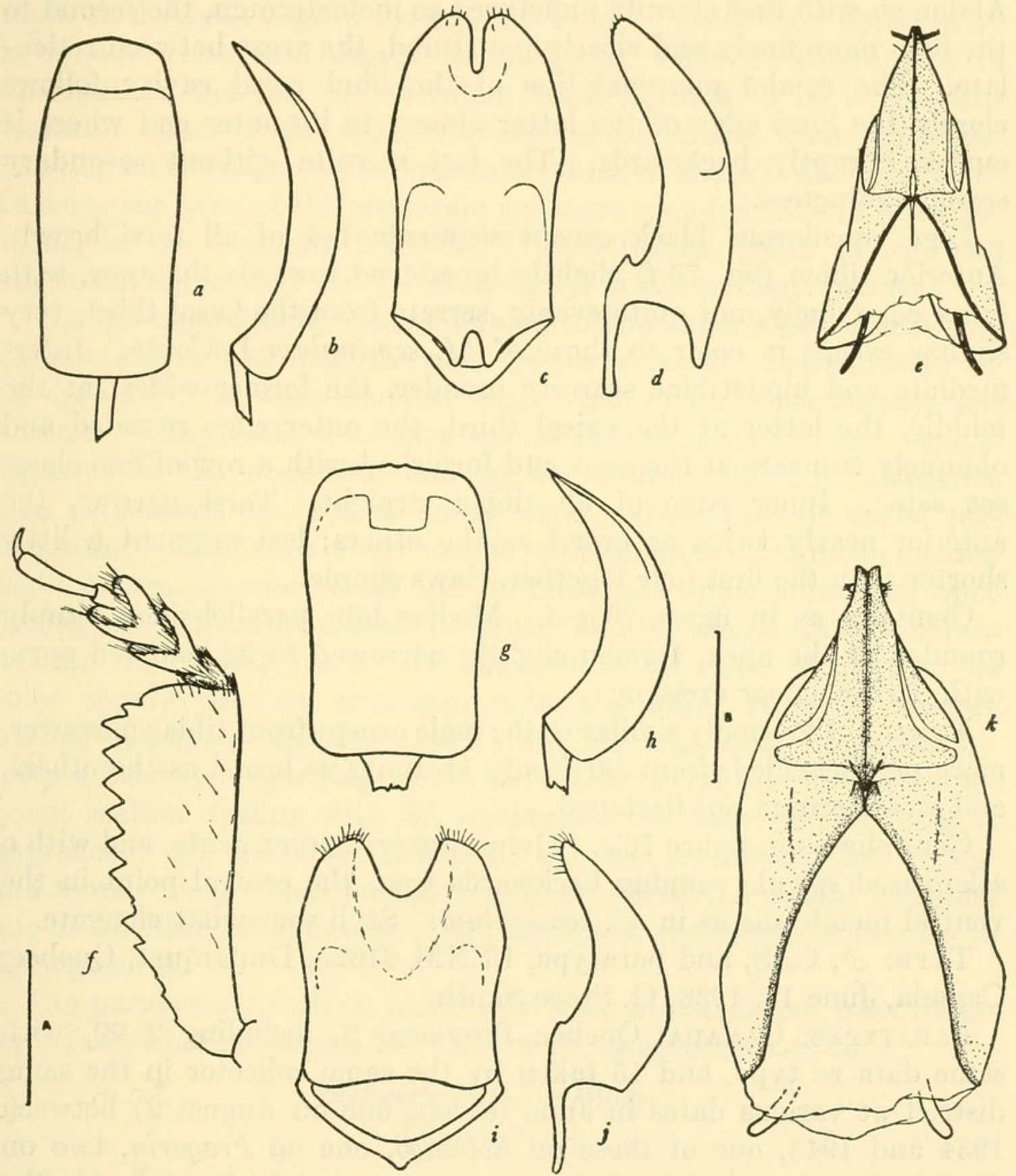

FigURE 76.- $a-f$, Meligethes canadensis, new species: $a$, dorsal view of median lobe of aedeagus; $b$, lateral view of same; $c$, dorsal view of tegmen of aedeagus; $d$, lateral view of same; $c$, ventral view of ovipositor; $f$, left front tibia and tarsus. $g-k, M$. atratus Olivier: $g$, dorsal view of median lobe of aedeagus; $h$, lateral view of same; $i$, dorsal view of tegmen of aedeagus; $j$, lateral view of same; $k$, ventral view of ovipositor. Scale A (a-d.f). $0.2 \mathrm{~mm}$.: scale B $(e, g-k), 0.25 \mathrm{~mm}$. 
Pygidium moderately coarsely and rugosely punctured, pubescence somewhat erect.

Ventral surface black. Prosternum coarsely and closely punctured, broadened posteriorly with apex rounded. Metasternum with punctures less coarse, about equal to eye facets, separated by $1 \frac{1}{2}$ diameters, surface between almost smooth; triangularly flattened in posterior two-thirds, and with a small longitudinal central area unpunctured. Abdomen with first sternite punctured as metasternum, the second to the fifth more finely and closely punctured, the areas between reticulate. The caudal marginal line of the hind coxal cavity follows closely the hind edge of the latter almost to its outer end where it curves abruptly backwards. The last sternite without secondary sexual characters.

Legs unicolorous black except segments 1-4 of all tarsi brown. Anterior tibiae (fig. 76,f) slightly broadened towards the apex, with outer edge finely, not quite evenly, serrate from the basal third, very similar except in color to those of $M$. seminulum LeConte. Intermediate and hind tibiae scarcely broader, the former widest at the middle, the latter at the apical third, the outer edge rounded and obliquely truncate at the apex and furnished with a row of fine closeset setae. Inner edge of all tibiae straight. Tarsi narrow, the anterior nearly twice as broad as the others; last segment a little shorter than the first four together, claws simple.

Genitalia as in figure $76, a-d$. Median lobe parallel-sided, simply rounded at the apex, tegmen slightly narrowed to its rounded apex, with narrow linear excision.

Female: Externally similar to the male except front tibiae narrower, more parallel-sided, front tarsi only $1 \frac{1}{2}$ times as broad as the others, and metasternum not flattened.

Genitalia as in figure 76,e. Ovipositor with apex acute, and with a sclerotized spicule running backwards from the central point in the ventral membrane as in M. seminulum. Styli somewhat elongate.

TyPe: $\sigma^{7}$, CAS, and paratype, USNM 61625, Duparquet, Quebec, Canada, June 18, 1938, G. Stace Smith.

Paratypes: Canada: Quebec Province: 3, including 2 우, with same data as type, and 15 taken by the same collector in the same district at various dates in June (except one on August 2) between 1934 and 1943, one of these on Solidago, one on Fragaria, two on Epilobium, others in lake-drift and on stones and plants beside the lake. Alberta: Edmonton, 4, June 1910 and July 1919, F. S. Carr. British Columbia: Stanley, 1, July 22, 1931, K. Graham; Beaton River, 15 miles northwest of, 1, by sweeping, June 8, 1950, P. Bubtsoff. Yukon: Dawson, 5, in USNM, June 1924, H. C. Fall.

Alaska: Mount McKinley National Park, 72, in USNM, June 1931, 
F. W. Morand; College, 2, in USNM, June, J. C. Chamberlain; Anchorage, 1, in USNM, May, N. Hoffman.

United States: California: Alta Meadow, Sequoia National Park, 9,000 ft., $\sigma^{\top}$, July 19, 1907, J. C. Bradley. Colorado: Argentine Road, 4 우, in USNM, Wickham. Utah: ㅇ, "Cornell U. Lot 909 Sub Schaeffer coll." ; Park City, ơ, in USNM, Hubbard and Schwartz.

Little variation is manifest in the material available except in the teeth on the outer edge of the anterior tibiae. These vary appreciably in number, size, and degree of sharpness, while an irregularity in distribution and size of individual teeth appears to be a constant feature. Some of the specimens are slightly duller than others depending on the degree of reticulation, which at times is almost absent. In some the sides of the pronotum are more rounded than in the type, while, in the examples from the United States, pallor of legs and antennae, apparently due to immaturity, is a prominent feature.

Though undoubtedly closely related to and superficially resembling $M$. seminulum LeConte, the new species is readily distinguished by its dark legs, the microscopical reticulation of its upper surface, the absence of any male secondary sexual character on the last ventral segment of the abdomen, and by its entirely different aedeagus. The ovipositor, too, by its longer styli and absence of apical pigmentation, constitutes a sure means of distinction. Its much smaller teeth on the anterior tibiae and its reticulate upper surface at once distinguish it from $M$. saevus LeConte; and its simple claws separate it from $M$ pinguis Horn. In addition to its other characters, its color should prevent confusion with the other Nearctic species. Among European species, apart from M. nigrescens Stephens (= picipes Sturm) - regarding which the reader is referred to the subsequent section dealing with $M$. seminulum LeConte-it most nearly approaches $M$. brachialis Erichson, but the smooth surface, wider and more robust tibiae, and divergent course of the caudal marginal line of the hind coxal cavity of the European species serve readily to distinguish it.

The paratypes to which name tabs were attached had been determined as either $M$. saevus LeConte or $M$. seminulum LeConte.

\section{Meligethes atratus Olivier}

FIgURE $76, g-k$

This species is added to the Nearctic list on the evidence of a single specimen in the British Museum collection bearing the data: "Metlakatla, Brit. Columbia. J. H. Keen 1915-355." This specimen agrees externally in all respects with Palaearctic examples, and on dissection it proved to be a female whose ovipositor is identical with that found in European specimens. 
M. atratus Olivier is well distinguished from the other Nearctic species by its large size (length 3-4 mm., width $1.6-2.1 \mathrm{~mm}$.) and by the following combination of its principal external characters: the black color of its upper surface except for the reddish translucency of the explanate side margins of the pronotum, its yellowish legs and antennae, the fine close punctures of its upper surface which on the elytra are elongate and finely cross-rugose, the nonreticulate surface between the punctures, and the evenly finely crenulate outer edge of its front tibiae. Added to these features are the characteristic forms of aedeagus and ovipositor that are shown in figure 76, $g-k$.

\section{Meligethes rufimanus LeConte}

FIgURE $77, a-e$

In 1857 LeConte described the species Meligethes rufimanus and $M$. moerens from examples taken in California and Oregon, respectively. Two years later he published the description of a third species, M. ruficornis, taken at Platte River, Kansas. The first two came subsequently to be accepted as identical, while the name ruficornis was found to be a homonym, Heer having used the same epithet in 1841. Consequently, in 1868, Harold changed this latter name to mutatus.

In 1871 Reitter, from a specimen taken by Kirsch in California, described briefly his variety californicus of $M$. aeneus Fabricius; clearly, he did not regard this American beetle as exactly identical with Palaearctic examples, though little evidence is apparent from his descriptions as to the grounds on which he based the distinction.

At a subsequent date Reitter sent a specimen of $M$. californicus to Horn, in America, who compared it with examples of rufimanus and found the two "perfectly identical," a fact that he recorded in 1879 . Because of this identity, both M.rufimanus LeConte and M. moerens LeConte came to be regarded as synonymous with $M$. californicus Reitter; later, all three were sunk as synonyms of $M$. aeneus Fabricius, and the latter name became included in the Nearctic list.

M. mutatus Harold, however, in spite of Horn's doubts as to its distinctness from rufimanus LeConte, maintained its specific identity, and was so treated by Parsons (1943), although he too found its distinction from aeneus Fabricius obscure and difficult of interpretation. Both these authors, moreover, stressed the variability of both species. Horn appeared doubtful as to the logic of avoiding further specific subdivision of mutatus, while at the same time retaining its distinctness from rufimanus on equally feeble characters, and Parsons considered that the variations of aeneus were sufficient to include mutatus within their range. 
My own now considerable experience with both Nearctic and Palaearctic material has led me to the conclusion that North American Meligethes which may have been variously determined as rufimanus, moerens, ruficornis, mutatus, or californicus, as well as many of those regarded as aeneus or brassicae, constitute but one single, although variable, species very closely related to but distinct from the Palaearctic $M$. aeneus Fabricius. Other specimens among Nearctic mate-
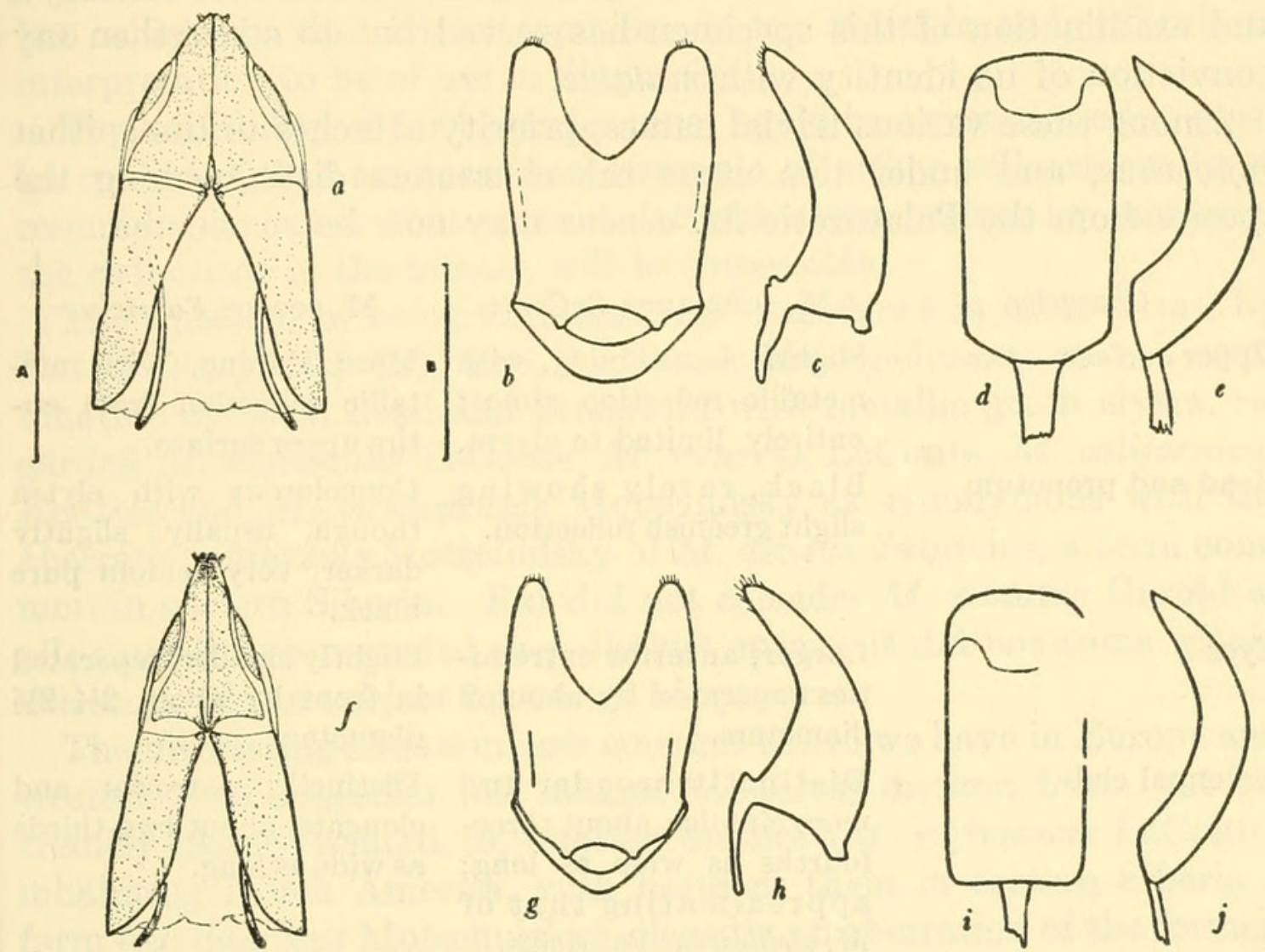

Figure 77.- $a-e$, Meligethes rufimanus LeConte: $a$, ventral view of ovipositor; $b$, dorsal view of tegmen of aedeagus; $c$, lateral view of same; $d$, dorsal view of median lobe of aedeagus; $e$, lateral view of same. $f-j, M$. aeneus Fabricius: $f$, ventral view of ovipositor; $g$, dorsal view of tegmen of aedeagus; $h$, lateral view of same; $i$, dorsal view of median lobe of aedeagus; $j$, lateral view of same. Scale A $(a, f), 0.25 \mathrm{~mm}$.; scale B $(b-\ell, g-j), 0.2 \mathrm{~mm}$.

rial that had been determined as belonging to this latter species have proved on critical examination to be unrecognized examples of $M$. simplipes Easton, and I have yet to see a specimen from America that I would regard as a true $M$. aeneus Fabricius. Thus I find myself in disagreement with such workers as Chittenden (1925) and Dr. Stuart W. Frost (quoted by Peng-Fi and Larson, ${ }^{1} 1949$ ), who regard it as a species introduced into North America.

\footnotetext{
1 The paper referred to, "Meligethes aeneus as a Factor in Muskmelon Breeding Program in Pennsylvania," was based on the determination by Mr. Henry Dietrich as M. aeneus Fabricius of specimens derived from the heavy infestation of the plants in 1948. During 1951 Prof. R. E. Larson very kindly sent me 188 beetles freshly collected off the same crop of Cucumis melo Linnaeus, and these, without exception, proved to be $M$. nigrescens Stephens (= seminulum LeConte).
} 
The type specimens of $M$. rufimanus LeConte, $M$. moerens LeConte, and $M$. ruficornis LeConte are in the LeConte collection housed in the Museum of Comparative Zoology and it has not been my good fortune to have the opportunity of examining them. The present whereabouts of the type specimen of M. californicus Reitter is a matter of doubt, for I am informed that it is not in the Hungarian National Museum in Budapest as presumed by Parsons. However, a cotype of M. rufimanus LeConte is in the British Museum (Natural History), and examination of this specimen has served but to strengthen my conviction of its identity with mutatus.

Among these various trivial names, priority attaches to the epithet rufimanus, and under this name the characters distinguishing the species from the Palaearctic $M$. aeneus may now be considered.

\section{Character}

Upper surface

Head and pronotum

Eyes

Antennal club

Pronotal punctures

Middle and hind tibise

Ovipositor

Aedeagus

\section{M. rufimanus LeConte}

Slightly less shining, with metallic reflection almost entirely limited to elytra. Black, rarely showing slight greenish reflection.

Larger, anterior extremities separated by about 2 diameters.

Distinctly broader and more circular, about threefourths as wide as long; approximating that of $M$. viridescens Fabricius.

Very slightly coarser, and closer, being separated by 1-11/2 diameters.

Usually somewhat broader with outer edge more evenly rounded.

As in figure 77, $a$, with apex blunter, the coxites distinctly broader in proportion to their length. Apex concolorous or only slightly darker.

As in figure $77, b-e$, with both lateral and median lobes more broadened towards the apex.
M. aeneus Fabricius

More shining, with metallic reflection from entire upper surface.

Concolorous with elytra though usually slightly darker, very seldom pure black.

Slightly smaller, separated in front by about $2 \frac{1}{4}-21 / 2$ diameters.

Distinctly narrower and elongate, about two-thirds as wide as long.

Slightly finer, separated by $1 \frac{1}{2}-2$ diameters.

Usually less broadened and outer edge less evenly rounded.

As in figure $77, f$, with apex much more acute, the coxites narrower. The extreme apex distinctly piceous.

As in figure $77, g-j$, with median lobe almost parallel-sided, scarcely broadened near the apex; the tegmen feebly broadened. 
The characters of greatest value are the form of the ovipositor, the shape and size of the antennal club, and the color of the pronotum. The elytra and undersurface exhibit no differences of note, while the variance in shape of the aedeagi, though deemed worth recording, is in practice so slight as to be of little value as a distinguishing character. It will be observed that no reference has been made to the extent and degree of explanation of the sides of the pronotum, a character which has been given prominent place by previous authors but which, in the writer's opinion, is too variable and difficult of interpretation to be of use in diagnosis.

The variability of both species must again be stressed, and it must be conceded that an occasional example of either will externally so resemble the other that certain determination, unless by means of the ovipositor in the female, will be impossible.

The question of color variation was considered in some detail by Ext (1920, pp. 35-36), who, by basing his conclusions on the combination of black head and pronotum with metallic green elytra, regarded $M$. rufimanus LeConte, $M$. moerens LeConte, $M$. californicus Reitter, and $M$. viridipennis Motschulsky as synonymous with the aberration dauricus Motschulsky of $M$. aeneus Fabricius, a form common in eastern Siberia. Ext did not consider $M$. mutatus Harold at all; since it was regarded as a distinct species it did not come within the scope of the subject matter of his paper.

The interesting situation now emerges where we have in Europe and western Asia a species ( $M$. aeneus Fabricius) distinct from, yet extremely closely related to, another species ( $M$. rufimanus LeConte) inhabiting North America, with between them in eastern Siberia a form (M. dauricus Motschulsky) allegedly an aberration of the former, yet showing coloring typical of the latter.

Happily, in the general collection of the British Museum there exist a single specimen (\&) labeled "Dauricus Motsch. nov. spec., Dauria," and two (fo) inscribed "viridipennis Mot. nov. spec., Dauria," with which may be included one other $\left(\sigma^{7}\right)$ bearing the data "motschoulskyi Murray ${ }^{2}$ n. sp. (viridiaeneus Motsch. $\left.{ }^{2}\right)$, E. Siberia." These I have been privileged to dissect and remount, thereby proving them identical with one another. Their great similarity to $M$. rufimanus LeConte is striking. Nevertheless I do not believe that they should be regarded as identical with this species, for though agreeing exactly in color they appear from other characters (including in particular the form of the ovipositor and the shape of the antennal club) to lie in an intermediate position between it and $M$. aeneus Fabricius.

No description published.

$309152-55-2$ 
The inevitable conclusion must be that all three forms-M. aeneus Fabricius, $M$. dauricus Motschulsky, and $M$. rufimanus LeConteconstitute divergent branches from a common ancestral stock. At the two extremes a barely sufficient differentiation has been reached to entitle us to regard them as distinct species. M. dauricus Motschulsky, in the intermediate position, should be considered as a subspecies of $M$. rufimanus LeConte, to which it lies closer both in its morphological characters and in its geographical distribution.

The synonymy of $M$. rufimanus LeConte thus becomes:

M. rufimanus LeConte, 1857

M. moerens LeConte, 1857

M. ruficornis LeConte, 1859, nec Heer, 1841

M. mutatus Harold, 1868

M. californicus Reitter, 1871

M. aeneus of American authors (ex parte), nec Fabricius, 1775 subspecies dauricus Motschulsky, 1849

subspecies viridipennis Motschulsky, 1866

The synonymy of $M$. aeneus Fabricius should be amended by the deletion of dauricus Motschulsky, rufimanus LeConte, moerens LeConte, viridipennis Motschulsky, and californicus Reitter.

In considering the distribution of this species, we note that LeConte's rufimanus was found in California, moerens in Oregon, and ruficornis in Kansas. Reitter's californicus derived from California. Horn recorded rufimanus from California and Oregon, and he considered mutatus to range from New York to Colorado. Parsons reiterated this distribution for mutatus but stressed its abundance in the mountainous region from Montana to Arizona and New Mexico. He reported aeneus from British Columbia (based no doubt on Criddle's 1922 record), and from Montana to California, Arizona, New Mexico, Tennessee, Indiana, Pennsylvania, and Maine. Blatchley (1910) included both aeneus and mutatus in his "Coleoptera of Indiana," while Blackwelder (1945) includes México within the range of "M. aenea $\mathrm{F}$."

Examples of $M$. rufimanus LeConte in my collection and those whose identity I have personally confirmed are derived from the localities that follow.

Canada: British Columbia: Lorna, Little White Mountain, Oliver. Saskatchewan: Pennant. Manitoba: Aweme.

United States: Washington: Spokane. Oregon: Mitchell. California: Very numerous localities throughout the State. Idaho: Lewiston, Coeur d'Alene. Nevada: Austin. Utah: Salt Lake City, Zion Canyon, Little Cottonwood Canyon, Wasatch Mountains, Monroe, Richfield, Bountiful, Alta, Lehi, Park City, Coalville. Arizona: Globe, Mount Lemmon, Oracle, Huachuca Mountains, Flag- 
staff, Chiricahua Mountains. Montana: Assinniboine, Helena, Yellowstone. Wyoming: Delano Ranch in Platte County. Colorado: Antonito, Gunnison, Lincoln County, Mount Lookout, Leavenworth Valley, Buena Vista, Denver, Garland, Mesa, Veta Pass, De Beque, Colorado Springs, Idaho Springs. New Mexico: Santa Fe, Las Vegas, Hot Springs, Magdalena. Nebraska: Pine Ridge, Plum Creek, West Point. Kansas: Douglas County, Lawrence.

Many of the records of American authors quoted above are based on misdeterminations, notably of $M$. simplipes Easton, and are therefore open to doubt. My own experience suggests that rufimanus does not occur at all in the Eastern States, where seminulum LeConte and simplipes Easton are the sole representatives of the genus, but that its distribution covers a wide area throughout the Western and Midwestern States, extending into Canada in the north, and probably into México in the south.

\section{Meligethes simplipes Easton}

Since describing this species from Ohio in 1947 a greater experience has shown it to be a not uncommon species widely distributed throughout many of the adjacent States. In collections $M$. simplipes Easton has generally been determined as $M$. brassicae Scopoli, an established synonym of $M$. aeneus Fabricius, and sometimes as $M$. mutatus Harold. In these guises there is no doubt that it has been responsible in large part for the confusion that has existed regarding the relationship of $M$. mutatus Harold and $M$. aeneus Fabricius, a subject that has been discussed in some detail above. Thus, in the collections of the British Museum, standing above the name $M$. brassicae Scopoli are six specimens from the W. S. Blatchley collection taken in Marion County, Indiana, one bearing the date June 1, 1928, and another labeled "Meligethes brassicae Scop. W. S. Blatchley det." These beetles, as also two of like derivation in the collection of New York State College of Agriculture, I find not only to be amply distinct from both $M$. aeneus Fabricius (= brassicae Scopoli) and rufimanus LeConte, but to agree exactly with $M$. simplipes Easton, and it is clear that Blatchley's record of "M. aeneus" in his "Coleoptera of Indiana" must be regarded as referring to this species.

The characters by which $M$. simplipes Easton may be distinguished from $M$. rufimanus LeConte (= mutatus Harold) were considered at the time of its original description (Easton, 1947). While the distinction between typical specimens of the two species is at once obvious, a small percentage of specimens exhibits a sufficient variation as to render diagnosis difficult, especially as regards size and proximity of punctuation. In the majority of these specimens, however, an 
accurate conclusion can be reached by a consideration of the greater degree of convexity and more shining surface of simplipes. Even so, a very small residuum persists in which final determination is virtually impossible, for here we are dealing with two species whose form of aedeagus and ovipositor differ so little as to be useless in differentiation. That such is the case should not be invoked as evidence of identity of the two species, for in Europe also a parallel exists, in which, however, one small additional character serves always as the final criterion. I refer to $M$. aeneus Fabricius and $M$. viridescens Fabricius, in which the chief differential characters, as in the case under consideration, depend on the size and proximity of the punctures of the elytra and the color of the legs. More closely finely punctured examples of the latter species are often indistinguishable from more diffusely punctured examples of the former, except by one small feature-the inconspicuous yet constant angulation on the lower edge of the intermediate femur in M. viridescens.

The distribution of $M$. simplipes as deduced from material personally determined covers the following localities.

Canada: Ontario: Michipicoten, Batchawana Bay.

United States: New York: Greene County, Catskill Mountains, West Point, Trenton. New Jersey: Phillipsburg. Pennsylvania: Easton, Allegheny. Maryland: Plummers Island, Hempstead. West Virginia: Fairmont, Mannington, Fort Pendleton. Ohio: Adams County, Highland County, Camden, New Concord. Tennessee: Great Smoky Mountains National Park, Flat Top Mountain, Chestoa, Unaka National Forest.

Except for the following records, determination of the above examples offered no difficulty: one example collected at Plummers Island, Maryland, on June 6, 1909, by W. L. McAtee; one example collected at Phillipsburg, New Jersey, on July 7, 1918, by J. W. Green; and three examples from the Schaeffer collection, now owned by Cornell University (New York State College of Agriculture), of which one bears a label "N. J." The first two would appear to be genuine examples of $M$. simplipes Easton. The last three examples give rise to greater difficulty, and I should have been inclined to call them $M$. rufimanus LeConte had not their place of origin been so much at variance with all my other experience. These three specimens apart (and it must be remembered that one of them bears only the hardly sufficient data “N. J.”), we find a complete absence of overlap in the areas of distribution of simplipes Easton and rufimanus LeConte, a factor which may legitimately be taken into consideration in the diagnosis of any particularly difficult example. 
M. simplipes is to be taken from April to August, abundantly in the flowers of Rubus canadensis Linnaeus, and less frequently on Syringa.

\section{Meligethes nigrescens Stephens}

Figure $78, a-e$

Examination of a considerable number of individuals of the beetle known in North America as Meligethes seminulum LeConte has shown a remarkable agreement in external characters with $M$. nigrescens Stephens (= picipes Sturm) (see Easton, 1951), a species very common throughout Europe and the British Isles and whose range includes Madeira and the Canary Islands, North Africa, Cyprus, the Caucasus, Siberia, and Arabia. Both show close to the apex of the last ventral segment the identical transverse smooth shining area with slightly raised ends that characterizes the male sex; moreover, dissection shows an identical aedeagus whose very distinct tegmen (fig. 78, $a-d$ ), is of a form quite unusual in the genus and, in the female, identical ovipositors characterized by the presence of a spicular sclerite arising from the midpoint and passing in a basal direction in the ventral membrane connecting the valvifers of the two sides (fig. 78,e).

That $M$. seminulum LeConte and $M$. nigrescens Stephens are identical is the obvious and only possible conclusion to be drawn from the above facts. Here we are dealing with one common Holarctic species, the identity of whose representatives in the Old and New Worlds has hitherto escaped recognition, a fact in part explained by Reitter's lack of opportunity to examine M. seminulum LeConte (Reitter, 1873, p. 71).

The synonymy of the species now becomes:

M. nigrescens Stephens, 1830

$M$. xanthoceros Stephens, 1830

M. picipes Sturm, 1845

M. funebris Förster, 1849

M. seminulum LeConte, 1857

M. saulcyi Reitter, 1872

M. pallipes Rey, 1889, nec Boheman, 1851

M. subsimilis Rey, 1889

M. circularis Sahlberg, 1903

As pointed out by Parsons, the distribution of this species is apparently discontinuous; abundant and widespread in Oregon, where it was first recorded by LeConte in 1857 , common in the Northeastern States, and met with in several of the Canadian provinces, it has yet to be reported from a vast area covering the central United States. Horn knew of it only from Oregon and from the north shore of Lake 
Superior. Parsons was able to include in its range Massachusetts and Pennsylvania in the eastern United States and Manitoba, Alberta, and Yukon Provinces in Canada, though some of these latter records may be based on misdetermined examples of $M$. canadensis.

My own collection contains material from States in the extreme west and in the east, as well as from Canada. In Oregon, M. nigrescens Stephens is widespread and especially abundant, occurring on a wide range of plants. Here it attacks, particularly, crops of Trifolium pratense Linnaeus grown for seed in the Corvallis district, the larval stage being passed in the flowers of this plant (the common Dutch clover) and of hairy vetch. Mr. E. A. Dickason of Oregon State College kindly sent me more than 2,000 examples from this source in July 1950.

Other specimens whose identity I have personally confirmed are from New York, New Jersey, Pennsylvania, Maryland, Ohio, and Washington. Mr. C. A. Frost tells me it is common in Massachusetts. In Erie County, Pennsylvania, this species constitutes a not inconsiderable pest on crops of muskmelon, Cucumis melo Linnaeus (see footnote, p. 91). Mr. R. J. Fitch sent me over 150 examples collected off dandelion and goldenrod at Vancouver, British Columbia, during May and August 1950. The British Museum possesses a single example from Metlakatla, British Columbia (J. H. Keen, 1915), while three specimens in the collection of the California Academy of Sciences were taken in turnip flowers at Dewdney in the same province.

Specimens in the collection of the U. S. National Museum are from the following localities: New Jersey (Radburn), Maryland (Priest Bridge, Arcadia, Aberdeen, Hempstead), and Oregon (Corvallis, Rickreall, Oswego, Scio, Dover).

\section{Meligethes saevus LeConte}

Figure $78, f-j$

This very distinct species appears to have no close relative among either the American or the European fauna, being at once separated from such species as nigrescens Stephens, canadensis, new species, and brachialis Erichson - to which in other characters it bears a superficial resemblance - by the large broad teeth along the outer edge of its front tibiae. These at first sight suggest an affinity with $M$. buduensis Ganglbauer, but such possibility is at once ruled out by a consideration of its other morphological details. M. maurus Sturm is superficially simulated in size and general form, though the group to which this species belongs has a typical aedeagal form entirely different from that of the Nearctic species. 
In saevus LeConte the aedeagus (fig. $78, g-j$ ) is somewhat elongate, its median lobe nearly parallel-sided and abruptly narrowed and bluntly pointed at the extreme apex, and its paramere of the usual bilobed form having a narrow parallel-sided central excision with simple lobes rounded and narrowed on the outer side. The ovipositor (fig. $78, f$ ) is elongate narrow and sharply pointed, and exhibits the ventral spicule noted under $M$. nigrescens Stephens and M. canadensis.

The recorded distribution of $M$. saevus covers a wide area including several of the Central States of the United States, to which the Canadian province of Manitoba may now be added on the strength of a single example in the collection of the California Academy of Sciences taken by N. Criddle at Aweme on June 11, 1923. Specimens
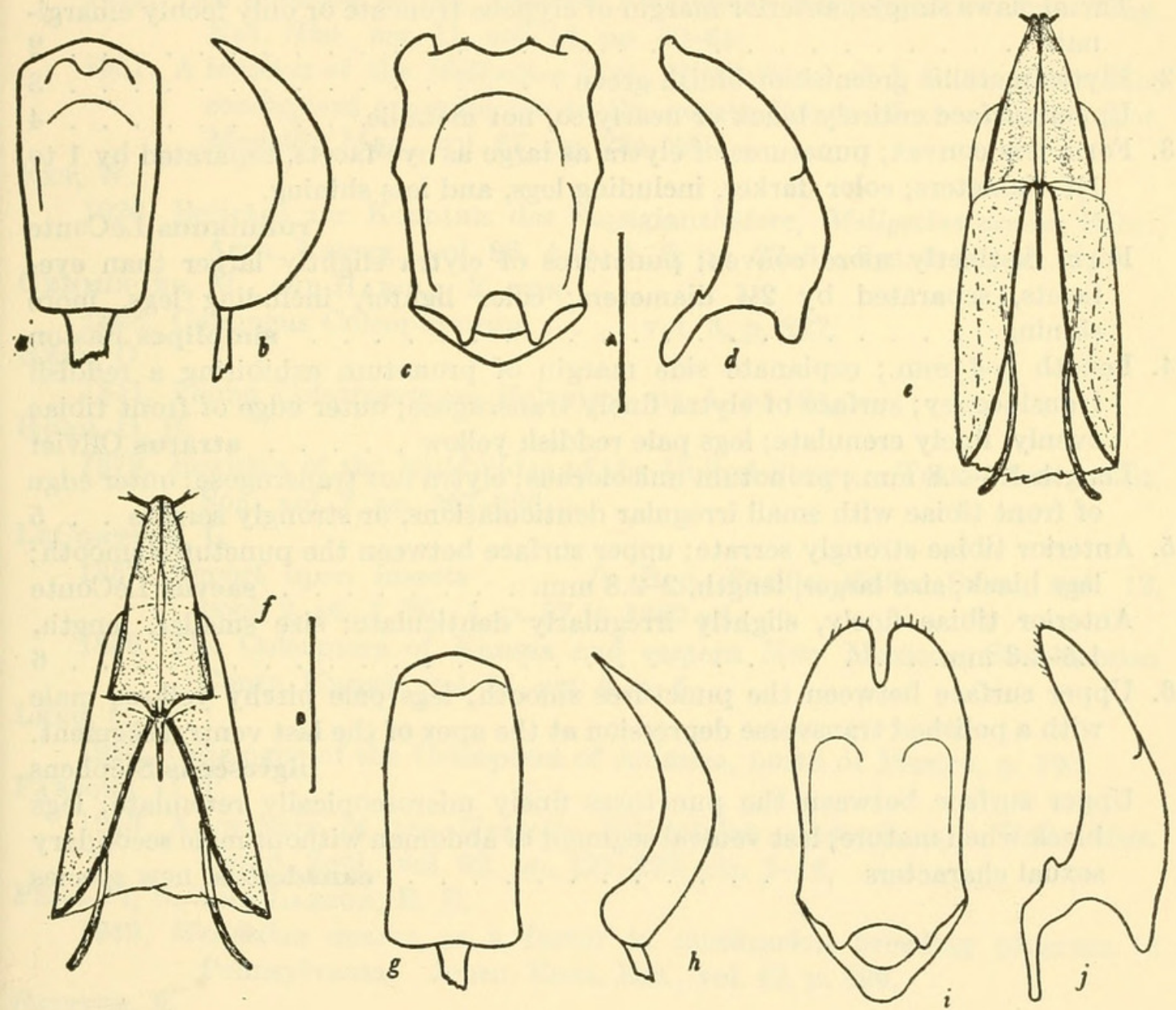

Figure 78.- $a-e$, Meligethes nigrescens Stephens: $a$, dorsal view of median lobe of aedeagus; $b$, lateral view of same; $c$, dorsal view of tegmen of aedeagus; $d$, lateral view of same; $c$, ventral view of ovipositor. $f-j, M$. saevus LeConte: $f$, ventral view of ovipositor; $g$, dorsal view of median lobe of aedeagus; $h$, lateral view of same; $i$, dorsal view of tegmen of aedeagus; $j$, lateral view of same. Scale A $(a-d), 0.2 \mathrm{~mm}$.; scale B $(e-j), 0.25 \mathrm{~mm}$. 
in the U. S. National Museum are from the following localities: Kansas (Topeka), Iowa (Lake Okoboji), North Dakota (Devils Lake).

\section{Meligethes pinguis Horn}

No additional example of this species has been recorded beyond the unique type from southern Newfoundland in the LeConte collection. It was considered by Horn to be allied to the Palaearctic M. (Acanthogethes) brevis Sturm, though Parsons found it "well within the range of variation" of his own series of $M$. (A.) fuscus Olivier.

\section{Key to the Nearctic species of Meligethes}

1. Tarsal claws toothed at base; anterior margin of clypeus somewhat deeply emarginate . . . . . . . . . . . . . . . . . . . . . . pinguis Horn

Tarsal claws simple; anterior margin of clypeus truncate or only feebly emarginate . . . . . . . . . . . . . . . . . . . 2

2. Elytra metallic greenish or bluish green . . . . . . . . . . . . . . . 3

Upper surface entirely black or nearly so, not metallic. . . . . . . . . . 4

3. Form less convex; punctures of elytra as large as eye-facets, separated by 1 to $1 \frac{1}{2}$ diameters; color darker, including legs, and less shining.

rufimanus LeConte

Form distinctly more convex; punctures of elytra slightly larger than eyefacets, separated by $21 / 2$ diameters; color lighter, including legs, more shining . . . . . . . . . . . . . . . simplipes Easton

4. Length 3-4 mm.; explanate side margin of pronotum exhibiting a reddish translucency; surface of elytra finely transrugose; outer edge of front tibiae evenly, finely crenulate; legs pale reddish yellow . . . . . atratus Olivier

Length 1.5-2.8 mm.; pronotum unicolorous; elytra not transrugose; outer edge of front tibiae with small irregular denticulations, or strongly serrate . . 5

5. Anterior tibiae strongly serrate; upper surface between the punctures smooth; legs black; size larger, length, $2-2.8 \mathrm{~mm}$. . . . . . . . . saevus LeConte

Anterior tibiae finely, slightly irregularly denticulate; size smaller, length, 1.5-2.3 mm. . . . . . . . . . . . . . . . . . . . . . . . . . . . 6

6. Upper surface between the punctures smooth; legs pale pitchy yellow; male with a polished transverse depression at the apex of the last ventral segment.

nigrescens Stephens

Upper surface between the punctures finely microscopically reticulate; legs black when mature; last ventral segment of abdomen without male secondary sexual characters . . . . . . . . . . . canadensis, new species 


\section{References}

BLACKWELDER, R. E.

1945. Checklist of the coleopterous insects of Mexico, Central America, the West Indies, and South America, pt. 3. U. S. Nat. Mus. Bull. 185, p. 408.

Blatchley, W. S.

1910. Coleoptera of Indiana. Bull. Indiana Dep. Geol. Nat. Res., No. 1, pp. 628-650.

Chittenden, F. H.

1925. Occurrence of Meligethes aeneus in the United States. Bull. Brooklyn Ent. Soc., vol. 20, p. 149.

Criddle, N.

1922. The Entomological Record for 1921. Ann. Rep. Ent. Soc. Ontario (1921), p. 63.

EAston, A. M.

1947. An addition to the Nearctic Nitidulidae (Coleoptera). Ann. Mag. Nat. Hist., ser. 11, vol. 14, pp. 60-64.

1951. A revision of the Meligethes (Col., Nitidulidae) of J. F. Stephens with consequent amendments to the nomenclature of the genus. Ent. Monthly Mag., vol. 87, pp. 281-284.

Ext, W.

1920. Beiträge zur Kenntnis des Rapsglanzkäfers, Meligethes aeneus Fabr., Arch. Naturg., vol. 86, Arb. A, 9, pp. 22-61, figs. 3-38, pls. 1, 2.

Gemminger, M., and Harold, E. von

1868. Catalogus Coleopterorum . . . , vol. 3, p. 827.

HeER, O.

1841. Fauna Coleopterorum Helvetica, pt. 1, p. 404.

Horn, G. H.

1879. Revision of the Nitidulidae of the United States. Trans. Amer. Ent. Soc., vol. 7, pp. 267-336.

LeConte, J. L.

1857. Report upon insects ... . In Rep. Pacific Railr. Surv., vol. 12, book 2, pt. 3, No. 1, p. 37 in 1860 ed.

1859. The Coleoptera of Kansas and eastern New Mexico. Smithsonian Contr. Knowl., vol. 11 , art. 6, p. 6.

LENG, C. W.

1920. Catalogue of the Coleoptera of America, north of Mexico, p. 195.

Parsons, C. T.

1943. A revision of the Nearctic Nitidulidae (Coleoptera). Bull. Mus. Comp. Zool., vol. 92, pp. 121-278, pls. 1-13.

Peng-Fi, L., and Larson, R. E.

1949. Meligethes aeneus as a factor in muskmelon breeding program in Pennsylvania. Journ. Econ. Ent., vol. 42, p. 399.

REITTER, E.

1871. Revision der europaïschen Meligethes-Arten. Verh. Nat. Ver. Brünn, vol. 9, pp. 39-169.

1873. Systematisches Verzeichniss der bis jetzt bekannten Meligethes-Arten.

Verh. Nat. Ver. Brünn, vol. 12, pp. 61-71. 


\section{$2 \mathrm{BHL}$ Biodiversity Heritage Library}

1955. "A revision of the Nearctic species of the beetle genus Meligethes (Nitidulidae)." Proceedings of the United States National Museum 104(3339), 87-103. https://doi.org/10.5479/si.00963801.104-3339.87.

View This Item Online: https://www.biodiversitylibrary.org/item/52773

DOI: https://doi.org/10.5479/si.00963801.104-3339.87

Permalink: https://www.biodiversitylibrary.org/partpdf/51036

\section{Holding Institution}

Smithsonian Libraries

\section{Sponsored by}

Smithsonian

\section{Copyright \& Reuse}

Copyright Status: Public domain. The BHL considers that this work is no longer under copyright protection.

This document was created from content at the Biodiversity Heritage Library, the world's largest open access digital library for biodiversity literature and archives. Visit BHL at https://www.biodiversitylibrary.org. 